\title{
Identification of Chikungunya virus nucleocapsid core assembly modulators
}

Sara E. Jones-Burrage ${ }^{\mathrm{a}, \pm}$, Zhenning Tan ${ }^{\mathrm{a}, \pm, \S}$, Lichun Li $^{\mathrm{b},}{ }^{\wedge}$, Adam Zlotnick $^{\mathrm{c}}$, Suchetana

Mukhopadhyay ${ }^{\mathrm{a}, ~ *}$

${ }^{a}$ Indiana University Bloomington, Department of Biology, Bloomington, IN 47405

${ }^{\mathrm{b}}$ Assembly Biosciences, Bloomington, IN 47405

${ }^{\mathrm{c}}$ Indiana University Bloomington, Department of Molecular and Cellular Biochemistry, Bloomington, IN 47405

${ }^{ \pm}$These authors contributed equally to this work

$\S$ Current Address: Aisera Inc., Palo Alto, CA 94304

^Current Address: Beckman Coulter Life Sciences, Indianapolis, IN, 46268

* Corresponding author: Suchetana Mukhopadhyay; Email: sumukhop@,indiana.edu; Phone: 812-856-3686 


\begin{abstract}
:
The alphavirus Chikungunya virus is transmitted to humans via infected mosquitos. Most infected humans experience symptoms which can range from short-term fatigue and fever to debilitating arthritis that can last for months or years. Some patients relapse and experience symptoms months or years after the initial bout of disease. The capsid protein of Chikungunya virus forms a shell around the viral RNA genome; this structure is called the nucleocapsid core. The core protects the genome during virus transmission and with the correct environmental trigger, this proteinaceous shell dissociates and releases the viral genome to initiate infection. We hypothesized that targeting compounds to interfere with the nucleocapsid core's function would constrain virus spread either by inhibiting the release of viral genomes during entry or by reducing the number of infectious virus particles assembled. We implemented a high throughput, in vitro, FRET-based assay to monitor nucleic acid packaging by purified Chikungunya capsid protein as a proxy for nucleocapsid core assembly and disassembly. We screened 10,000 compounds and found 45 that substantially modulated the assembly of core-like particles. A subset of compounds was selected to study their effects in virus-infected vertebrate cells. Our results show that four compounds inhibit infectious virus production by at least $90 \%$ in a dose-dependent manner. The most promising inhibitor was tested and found to reduce the amount of nucleocapsid cores inside the cell during Chikungunya virus infection. These compounds could be the foundation for anti-viral therapeutics.
\end{abstract}

Keywords (6 max): Chikungunya virus; antiviral compounds; nucleocapsid core; fluorescence quenching-based high throughput screen 


\section{Highlights}

- A FRET-based assay to detect nucleic acid packaging by Chikungunya virus capsid protein

- Identification of small molecules that modulate core-like particle assembly

- A subset of compounds that interfere with in vitro assembly also inhibit Chikungunya virus production in cell culture

- Identification of antiviral molecules that may not be identified by assays using reporter viruses

- Potential starting compounds for developing direct-acting antivirals 


\section{Introduction}

Chikungunya virus (CHIKV) is a re-emerging alphavirus that is spread by a mosquito vector to humans and other vertebrates $(1,2)$. An estimated 3 million people are affected annually by CHIKV and approximately 80-95\% develop symptoms 2 to 12 days after being bitten by an infected mosquito $(1,3,4)$. Infected individuals typically suffer from short-term fever, fatigue, and joint pain; however, approximately $25-48 \%$ develop long-term debilitating arthritis that can persist for months or years $(2,5,6)$. Previously, CHIKV outbreaks were limited to tropical and subtropical Asia and Africa, but outbreaks have now been reported in Europe, North America, South America, and the Caribbean (2). This expansion is due in part to a mutation in a viral protein, which supportstransmission of the virus in both the Aedes aegypti and Aedes albopictus mosquito vectors (7). A number of inhibitors of CHIKV have been identified including compounds that target the virus lifecycle including genome replication, viral protein synthesis, and virus egress, specifically the interaction of the core with the viral spikes (8-19). These compounds, however, are effective only at high concentrations or resistance is easily acquired. Antiviral compounds that target host factors required by CHIKV reduce viral titers but these compounds are by definition affecting normal cellular function (10, 20-22).

Antivirals that target the functions of capsid proteins of approximately half a dozen other eukaryotic viruses have been successful direct acting antivirals. While the core is modulated in all the inhibitors identified, their mode of action and lifecycle stage varies. Work with polio and dengue viruses $(23,24)$ show the that when antivirals (V-073 for polio and ST-148 for dengue) target the capsid/core proteins, the virus is less likely to develop drug resistance because the viral capsids/cores will contain both drug-susceptible and drug-resistant capsid proteins. Because of this chimera oligomer, the drug is still effective despite mutations arising. Additional studies 
have shown that ST-148, is thought to make the dengue core more rigid by promoting capsid contacts, thus interfering with the packaging and disassembly of viral RNA $(25,26)$. One could envision that a dengue core containing even a few core proteins that have stronger contacts with adjacent subunits would disrupt the overall assembly of the core. Small molecules have been identified that target Hepatitis B virus capsid assembly (27-31); heteroaryldihydropyrimidines compounds promote assembly and lead to empty or misassembled particles that have fallen into kinetic traps $(27,30)$. In contrast, inhibitors of enteroviruses, such as the WIN compounds for rhinoviruses, prevent the disassembly of the capsid particle $(32,33)$. Here, the two most efficient WIN compounds bind to a pocket in the capsid protein inhibiting breathing and disassembly of the capsid $(33,34)$. Two groups of antivirals that target HIV capsid have been identified. Small molecules will interfere with the virion maturation by targeting the cleavage and rearrangement of capsid, which is necessary for infectious viron maturation (35-42). The second group of antivirals interfere with the capsid -capsid protein interactions, and interfere with assembly, genome packaging, and uncoating $(40,43,44)$.

CHIKV, like other Alphaviruses (Ross River virus, Venezuelan Equine Encephalitis virus, Eastern Equine Encephalitis virus) are enveloped, positive-sense RNA viruses (45). Particles have icosahedral symmetry and are organized with (i) an internal nucleocapsid core, consisting of the capsid protein and RNA genome, (ii) a host-derived lipid bilayer surrounding this core, and (iii) a shell of viral glycoproteins on the particle surface which are required for cell entry (46, 47). The capsid protein consists of two domains, a disordered N-terminal domain that interacts with the viral RNA, and a C-terminal chymotrypsin-like domain that makes up of the outer surface of the core. The C-terminal domain of capsid protein interacts with the endo domain of 
one of the viral glycoproteins, E2. The different roles of the capsid protein in the viral lifecycle require multiple interactions of capsid protein.

Assembly of alphavirus nucleocapsid cores can be recapitulated in vitro; these are called core-like particles (CLPs) (48). CLPs can be assembled by mixing recombinant capsid protein with viral RNA. CLPs are also formed when non-viral cargo (e.g., single-stranded DNA and RNA oligonucleotides, polyanion small molecules, or gold particles coated with nucleic acid) are mixed with capsid protein (49). CLPs can be encapsidated by viral glycoproteins, and the newly formed virus-like particles are able to enter and disassemble within a new cell $(50,51)$. A $27 \mathrm{mer}$ DNA oligo interacts in a 1:1 molar ratio to neutralize the basic N-terminus of the capsid protein $(52,53)$ to initiate CLP assembly. CLPs are $40 \mathrm{~nm}$ in diameter and structurally similar to cores in virions (52-55). The efficiency of CLP assembly can be regulated by ionic strength. Low ionic strength buffers promote CLP assembly and inhibit CLP disassembly. High ionic strength buffers will inhibit CLP assembly and will promote CLP disassembly (48-50, 52-54, 56). The need for anionic cargo and the sensitivity to ionic strength indicate that the capsid protein-capsid protein interactions during assembly are extremely weak and that assembly depends on electrostatic interaction with cargo.

In this study, we sought to identify small molecule modulators of CHIKV CLP assembly (48, $53,57)$. We monitored the fluorescence quenching of fluorophore-labelled oligonucleotides to monitor nucleic acid packaging. We screened a 10,000 compound library in vitro. From the 45 compounds identified in vitro, 12 were selected for validation in cell culture with CHIKV. We report that four compounds could block the production of infectious CHIKV particles by at least $90 \%$ in a dose-dependent manner. Furthermore, the compound that reduced titers the most, 
reduced the amount of cytoplasmic cores present in infected cells, consistent with this compound targeting the nucleocapsid core during infection.

\section{Materials and Methods}

\subsection{Capsid and oligomer preparation}

The capsid protein from CHIK 181/25 (58) was cloned into the pET29 vector and expressed in Rosetta2pRARE2 cells as done previously for other alphavirus capsid proteins $(17,18,48,54$, 59). For ease of purification, we included a 6-His tag at the N-terminus prior to the first amino acid. Cells were grown at $37^{\circ} \mathrm{C}$, when the OD600 was between $0.4-0.6,1 \mathrm{mM}$ IPTG was added. Cells were grown for an additional 4 hours. Cells were pelleted and resuspended in $20 \mathrm{mM}$ sodium phosphate buffer containing $2 \mu \mathrm{g} / \mathrm{ml}$ leupeptin, $2 \mu \mathrm{g} / \mathrm{ml}$ aprotinin, and $1 \mathrm{mM}$ PMSF to a final cell density of $0.06-0.08 \mathrm{~g} / \mathrm{ml}$ (53). Samples were lysed using a cell cracker or a sonicator, sodium chloride was added to a concentration of $500 \mathrm{mM}$, and then lysates centrifuged at in a Beckman JA17 rotor at $23000 \mathrm{x} g$ or 45 minutes at $4^{\circ} \mathrm{C}$. Clarified supernatant was applied to a $5 \mathrm{ml}$ HisTrap column (GE Lifesciences) and after washing with 5 to 10 column volumes of 20 mM sodium phosphate, $\mathrm{pH} 7.4,500 \mathrm{mM} \mathrm{NaCl}$, and $10 \mathrm{mM}$ imidazole until A280 and A260 returned to baseline, the protein was eluted with a similar buffer but with $800 \mathrm{mM}$ imidazole. For further purification, peak fractions were collected and diluted to $0.25 \mathrm{M} \mathrm{NaCl}$ with $20 \mathrm{mM}$ sodium phosphate, $\mathrm{pH}$ 7.4. Samples were applied to a HiTrap SP column (GE Lifesciences), washed with $20 \mathrm{mM}$ HEPES pH 7.4, $0.25 \mathrm{M} \mathrm{NaCl}, 5 \mathrm{mM}$ EDTA and then eluted from the column using $20 \mathrm{mM}$ HEPES pH 7.4, 1.3 M NaCl, and 5 mM EDTA. Fractions with an absorbance substantially above background and an 260/280 absorbance ratios less than 0.6 were pooled, concentrated with a centricon $10 \mathrm{~K}$ concentrator, and buffer exchanged into $20 \mathrm{mM}$ 
HEPES and $150 \mathrm{mM} \mathrm{NaCl}$. The resulting material served as our stock solution. Protein concentration was determined by measuring absorbance at $280 \mathrm{~nm}$ using an extinction coefficient of $39670 \mathrm{M}^{-1} \mathrm{~cm}^{-1}$.

\subsection{High Throughput Screen}

High throughput screen assays were performed at the Chemical Genomics Core Facility at IUPUI (Indianapolis, IN). Each compound of the Chembridge 10K library (San Diego, CA; kindly provided by Assembly Biosciences) was prepared as a 1mM stock in 100\% DMSO in 384-well plates. We conducted two screens by adjusting the assembly conditions. For the inhibitor screen, we used a final $\mathrm{NaCl}$ concentration of $320 \mathrm{mM}$ to achieve approximately $75 \%$ assembly of CLPs and focused on compounds that inhibited assembly. In the second screen, we used a final $\mathrm{NaCl}$ concentration of $570 \mathrm{mM} \mathrm{NaCl}$ to achieve approximately $30 \%$ assembly of CLPs and focused on compounds that promoted assembly. The final reaction for each screen contained $0.25 \mu \mathrm{M}$ of capsid protein, $0.25 \mu \mathrm{M}$ of oligomer, and $10 \mu \mathrm{M}$ of compound in a total volume of $25 \mu \mathrm{l}$ per well in a 384-well plate (Greiner bio one).

For the screens, capsid protein stock was diluted to $0.417 \mu \mathrm{M}$ in either 534.4 or $951.9 \mu \mathrm{M}$ $\mathrm{NaCl}$ in 20 mM HEPES, pH 7.5 buffer. A 27mer oligomer (5'-TACCCACGCTCTCGCAGTCA TAATTCG) was prepared in 20 mM HEPES, pH 7.5 buffer, without any $\mathrm{NaCl}$. The oligomer mixture contained unlabeled 27mer, Cy3-5' labeled 27mer, and Cy5-5' labeled 27mer at a 1:2:2 ratio (IDT).

For reactions with compounds, $15 \mu \mathrm{l}$ of $0.417 \mu \mathrm{M}$ capsid in the appropriate $\mathrm{NaCl}$ solution was first added to each well of a 384-well plates (MultiFlo FA Microplate Dispenser, Bio Tek). Then, $0.25 \mu$ of compound ( $1 \mathrm{mM}$ stock in DMSO) was added (Freedom EVO 100 liquid 
handler, Tecan). After a 5-10 minute incubation at room temperature to initiate compoundprotein interaction, $10 \mu \mathrm{l}$ of the $0.625 \mu \mathrm{M}$ oligomer mixture was added to a final volume of 25 $\mu 1$. Plates were centrifuged briefly and incubated at room temperature for 2 hours in the dark. Finally, the fluorescence signal was recorded with an EnVision 2102 Multilabel Plate Reader (Perkin Elmer) with monochromators set to $531 \mathrm{~nm}$ excitation and $595 \mathrm{~nm}$ emission.

Each assay consisted of thirty-two 384 plates and each plate contained a series of controls. One column (16 wells) controlled for assembly in the presence of increasing ionic strength to ensure the fluorescence signal inversely correlated to assembly. A second column had assembly reactions at the salt concentration being used in the assay $(320 \mathrm{mM}$ for inhibitors and $570 \mathrm{mM}$ for promoters) to give a baseline fluorescence signal for $75 \%$ assembly and $30 \%$ assembly, respectively. The third and fourth columns contained reactions with maximal assembly (100 $\mathrm{mM}$ $\mathrm{NaCl})$ and minimal assembly $(800 \mathrm{mM})$ to establish the minimum and maximum fluorescence signals, respectively. Also included were capsid protein/no oligonucleotide controls.

\subsection{High Throughput Data Analysis}

HTS data quality was monitored using the standard curve as well as the positive and negative controls on each plate. Data points were normalized by averaging of all the data points in the same position across all plates to eliminate systematic instrumental error on specific wells. We defined potential hits in the following way to minimize random error and allow comparison of chemical structures: hits are 3 sigma (i.e. 3 standard deviations of the signal distribution) away from the average of the primary screen and 2 sigma from the average of the secondary screen. All analysis was performed using the R project for Statistical Computing (60). 


\subsection{Tissue culture reagents}

All tissue culture experiments were performed using the baby hamster kidney cell line BHK21, here referred to as BHK cells. Cells were passaged in minimum essential medium (MEM) supplemented with non-essential amino acids, penicillin-streptomycin, and L-glutamine in 10\% fetal bovine serum (Corning Cellgro, Manassas, VA) and grown at $37^{\circ} \mathrm{C}$ and $5 \% \mathrm{CO}_{2}$.

\subsection{Virus preparation and titering}

The CHIK 181/25 virus used in this study was a generous gift from Dr. Terence Dermody's lab. Nanoluc was cloned into the hypervariable loop of nsP3, after amino acid 490, or after capsid, as described in the literature $(61,62)$. Infectious virus was generated as described in (63). Briefly, SacI-linearized CHIK-capsid::nLucFM2 $\alpha$ cDNA plasmid was transcribed into infectious RNA in vitro using a synthetic cap analog and SP6 RNA polymerase (New England BioLabs, Ipswich, MA). RNA was electroporated (1500 V, $25 \mu \mathrm{F}, 200 \Omega$ ) into BHK cells resuspended in phosphate-buffered saline (PBS) in a 2-mm cuvette. Upon display of significant cytopathic effect, media were harvested and clarified at 5,000 $\times g$ for $5 \mathrm{~min}$.

Plaque assays, as described in (63), were used to determine the amount of infectious virus present and was measured as plaque-forming units (PFUs) per mL. Briefly, serial dilutions of the media harvested from virus-infected cells were added to BHK monolayers for $1 \mathrm{~h}$ at room temperature while rocking gently. Cells were overlaid with $1 \%$ low-melt agarose, $1 \times$ complete MEM, and10\% fetal bovine serum. At 48 hpi $1 \mathrm{~mL}$ of complete MEM with $10 \% \mathrm{FBS}$ was added to each well. Plaques were detected at 72 hpi by formaldehyde fixation and crystal violet staining. 


\subsection{Compound toxicity in uninfected cells.}

BHK cells (30,000 cells/well) were plated into a 96-well plate approximately 24 hours prior to adding the compounds. The supernatant was aspirated off and $100 \mu 1$ fresh phenol red-free complete MEM with $10 \%$ FBS was added. Then, compounds dissolved in DMSO were added to a final concentration of $10 \mu \mathrm{M}$. Plates were incubated for 24 hours at $37^{\circ} \mathrm{C}$ with $5 \% \mathrm{CO}_{2}$. Then, media was aspirated and we assessed ATP levels in cell lysates using the CellTiter-Glo® Luminescent Cell Viability Assay (Promega). Briefly, $30 \mu \mathrm{L}$ of cell-titer glow reagent was added to each well and, after 10 minutes, the luminescence was measured using a Synergy H1 plate reader (BioTek).

\subsection{Antiviral assays}

To test if compounds inhibited infectious virus production, 300,000 BHK cells/well were plated into 12 -well plates approximately 24 hours prior to virus infection. The day of the infection, the supernatant was aspirated and the CHIK capsid:nLucFM2 $\alpha$ virus was added at an MOI $=0.01$ in a final volume of $200 \mu \mathrm{L}$. After a 1 hour adsorption period at room temperature, cells were washed twice with PBS to remove unabsorbed virus and then $1 \mathrm{~mL}$ of media was added. Compounds were added either during absorption and/or after washing the cells with PBS depending on the experiment. For mock-infected cells, DMSO alone was added. For dose response assays, serial dilutions of each compound were made using DMSO so that the same volume of DMSO was added to culture media. Twenty-four hours after completion of adsorption, supernatants were collected and viral titers determined by plaquing the cells on BHK cells as described above. 


\section{8 qPCR to measure particle numbers}

At $24 \mathrm{hrs}$ post infection, supernatants from infected BHK cells were collected and clarified (5000 x g for $5 \mathrm{~min}$ at room temperature). Virus concentration was determined by RT-qPCR using $5 \mu$ of each supernatant as template for cDNA synthesis and the method described (64). Primers used were Forward: 5'ggaataaagacggatgatagc and Reverse: 5'ggtcgggaatgaaatttttcc. The absolute quantities of viral RNAs were determined using a standard curve of in vitro transcribed RNA.

\subsection{Nucleocapsid core isolation from infected cells}

Cytoplasmic cores from virus-infected cells were isolated as described previously (65). Briefly, four $100 \mathrm{~mm}$ dishes of BHK cells were infected with $\mathrm{CHIK}$ at a MOI=0.1. Virus was allowed to adsorb for one hour and then cells were washed twice with PBS. To two plates, serum-free media and 1\% DMSO was added, and to the other two plates, $1 \mu \mathrm{M}$ 4BSA (in DMSO) in serum-free media was added. Cells were harvested 24 hours post infection, pellets were washed with ice-cold PBS, resuspended in $1 \mathrm{ml}$ of TNE buffer $(10 \mathrm{mM}$ TrisCl, $\mathrm{pH} 7.510$ $\mathrm{mM} \mathrm{NaCl}$, and $20 \mathrm{mM}$ EDTA). Cells were incubated on ice for 20 minutes. The nuclei were removed by spinning at $1000 \times \mathrm{g}$ for 10 minutes at $4^{\circ} \mathrm{C}$. Supernatants were loaded on $10-40 \%$ sucrose gradients in TNE $+0.1 \%$ Triton X-100 buffer. Gradients were spun in SW41 rotor for 2.5 hours at $32,000 \times \mathrm{g}$ at $15^{\circ} \mathrm{C}$. Fractions collected and analyzed by western blot (65).

\section{Results and Discussion}

\subsection{A high throughput screen to identify compounds that modulate core-like particle assembly}


We chose to identify antiviral compounds that target the CHIKV capsid protein because the capsid protein must make several crucial interactions to generate infectious virus. The core protects the viral RNA genome during virus transmission, but must dissociate under the correct physiological conditions for virus replication (46). In addition, the properly assembled core interacts with the cytoplasmic domain of the viral glycoprotein E2 (66) suggesting the assembly of the core is critical for particle budding. In vitro assembled CLPs are structurally and functionally similar to nucleocapsid cores from infected cells $(50,51,54)$ making them ideal systems for studying core assembly $(48,49,52,53,59,67-69)$.

CLPs can be assembled in vitro by mixing equimolar ratios of capsid protein and $27 \mathrm{mer}$ DNA oligomers in the presence of $100 \mathrm{mM} \mathrm{NaCl}$, as previously demonstrated (52). For those experiments $3 \mu \mathrm{M}$ capsid protein and $3 \mu \mathrm{M}$ oligonucleotide were used. CLPs formed rapidly at room temperature and were visualized by dynamic light scattering, gel shift assay, and transmission electron microscopy $(48,53,54)$. To examine CLP assembly in a high throughput format we used a fluorescent output: Cy3- and Cy5-labeled 27mer oligomers were used as cargo and DNA packaging was observed by fluorescence resonance energy transfer (FRET) for identification and quantification of CLP assembly (57). When the labeled oligomers are incorporated into core-like particles, the fluorophores are forced into close proximity to one another and FRET occurs, resulting in a decrease in the Cy3 emission signal and a corresponding increase in the Cy5 emission signal (Figure 1). We tested different ratios of unlabeled:Cy-3 labeled:Cy5-labeled 27mer oligomer and found the ratio of 1:2:2, respectively, provided the largest fluorescence range while minimizing self-quenching due to $\mathrm{Cy} 3-\mathrm{Cy} 3$ and $\mathrm{Cy} 5-\mathrm{Cy} 5$ interactions. We observed that the decrease in $\mathrm{Cy} 3$ fluorescence had a greater dynamic range than the increase in Cy5 fluorescence, thus we used the change in the Cy3 fluorescence as a read- 
out for oligo packaging and CLP assembly. We found that $1.5 \mu \mathrm{M}$ capsid protein and $1.5 \mu \mathrm{M}$ total oligomer provided a strong signal to discriminate between packaged and unpackaged DNA. This ratio still maintained the 1:1 mole ratio while reducing the concentrations of capsid protein and oligomer used.

We used this FRET-based in vitro assay $(48,53,54,57)$ to screen 10,000 compounds for their ability to affect fluorescence as a proxy for their ability to modulate CLP assembly. We anticipated the following outcomes (Figure 1). Compared to a control, compounds could inhibit CLP formation resulting in more free nucleotide and higher fluorescence (Figure 1B); they could promote assembly in the absence or reduced amount of DNA also resulting in higher fluorescence (Figure 1C); they could enhance the overall amount of assembly resulting in more oligonucleotide packaging and lower fluorescence (Figure 1D); they could increase the amount of oligos packaged in a CLP, also resulting in lower fluorescence (Figure 1E). Our screen, without other assays, does not determine which scenario is occurring, merely that there is a change in the CLP assembly process.

To maximize our chances of identifying assembly enhancing and inhibiting compounds we screened compounds under two different ionic strength conditions. In the first screen, we used low ionic strength conditions where packaging was robust and fluorescence suppressed. Compounds that decrease the packaging of oligomers, thereby raising the fluorescence signal from $\mathrm{Cy} 3$, would be readily identified (Figures $1 \mathrm{~B}$ and $1 \mathrm{C}$ ). In the second screen, we used moderate ionic strength conditions where packaging was reduced and fluorescence higher; this was used to identify compounds that decrease the fluorescence signal from $\mathrm{Cy} 3$, suggesting an increase in the packaging of oligomers (Figures 1D and 1E). 
To test the core modulation properties of the compounds, CLP assembly was initiated by adding the oligomer mixture to purified capsid protein and $10 \mu \mathrm{M}$ compound in the appropriate ionic strength buffer. In the lower ionic strength screen, we found 70 molecules out of 10,000 that resulted in an increase in Cy3 fluorescence by at least 3 standard deviations from the mean fluorescence (Figure 2A, dark blue line, $+3 \sigma$ ). In the moderate ionic strength screen, we found 36 compounds that decreased Cy3 florescence by at least 3 standard deviations from the mean florescence (Figure 2B, dark green line, $-3 \sigma$ ). From our two screens we had at least 106 compounds with CLP modulating properties in vitro (Figures $2 \mathrm{~A}$ and $2 \mathrm{~B}$ ).

There were 19 compounds that increased fluorescence in both the low and moderate ionic strength screens (Figure 3A). Since the moderate ionic strength screen was not as sensitive to detecting increased fluorescence, we looked for compounds that increased fluorescence by 2 standard deviations in this screen that also increased fluorescence by 3 standard deviations in the low ionic strength. In a similar process, 26 compounds that increased fluorescence were identified in both screens (Figure 3B).

We determined the efficacy of the 45 putative antiviral compounds based on in vitro dose response of CLP assembly (Supplemental Figure 1). These assays were performed using standard conditions of $1.5 \mu \mathrm{M}$ capsid protein, $1.5 \mu \mathrm{M}$ oligomer, and either $320 \mathrm{mM}$ or $570 \mathrm{mM}$ $\mathrm{NaCl}$. The $\mathrm{AC}_{50}$ (defined as half-maximal activity concentration) of the compounds ranged from 1 to $9 \mu \mathrm{M}$. Based on efficacy, 12 compounds, six that increased fluorescence and six that decreased fluorescence, were selected for further characterization.

\subsection{Production of CHIKV infectious particles is reduced with core modulating compounds}


The screen to identify CLP assembly modulators was performed using purified components to maximize the likelihood of finding a compound that interfered with capsid protein-oligo or capsid protein-capsid protein interactions rather than an off-target cellular effect. Now we wanted to determine if the compounds identified as core modulators in vitro were also effective during viral infections in cell culture.

The 12 selected compounds were tested for toxicity and antiviral efficacy. To test toxicity, we cultured BHK cells in the presence of $10 \mu \mathrm{M}$ of each compound for 24 hours and then (i) assessed cell health by measuring cellular ATP levels using a commercial luciferase-based assay and (ii) assessed cellular morphology by microscopy. The 24-hour time point was selected because CHIKV-infected BHK cells show cytopathic effect at this time post-infection. At 10 $\mu \mathrm{M}$, eight compounds were tolerated well by cells and showed ATP levels similar to control cells treated with DMSO (Figure 4). In contrast, compounds MA, NTU, NDBA, and 4PBSA were detrimental to cells based on reduced levels of ATP and altered cellular morphology.

Based on these findings, we only tested the eight non-toxic compounds (4CA, 4BA, 1PA, 7AA, 4BSA, NNU, 2P, and 2CA) for their ability to inhibit infectious CHIK virus production. We performed a series of experiments where the time at which the compounds were added was varied relative to CHIK virus adsorption: BHK cells were incubated with the compounds continuously (Figure 5A), only after viral absorption (Figure 5B), or only during viral absorption (Figure 5C). In all cases, supernatants from each of these experiments were collected 24 hours post virus infection and assessed for infectious virus by plaque assays. All eight of the compounds had anti-viral activity (Figure 5), albeit to differing extents depending on when the compound was added during the infection. 
When $10 \mu \mathrm{M}$ of compound was incubated with CHIKV-infected BHK cells continuously (Figure 5A), all eight compounds inhibited infectious virus production by at least $50 \%$ when compared to the DMSO-treated control cells. Compound 4BSA was the most potent inhibitor of infectious virus production and suppressed viral titer by at least $90 \%$. When compounds were added to cells after virus absorption (Figure 5B), they all reduced the amount of infectious virus produced by at least 50\%, except for 4CA and 5NSBA. In the final time-of-addition experiment, we treated BHK cells with compound for only 1 hour during absorption of the virus (Figure 5C) and found that compounds 5NSBA, 1PA, and 7AA were much less effective and no longer inhibited production of infectious virus by $50 \%$.

The eight compounds that exhibited antiviral activity were identified from the screen that only contained capsid protein and oligomer. Therefore, we hypothesized the compounds primarily interfere with an aspect of core assembly or disassembly. We cannot say if the antivirals interfere with capsid-nucleic acid, capsid protein-capsid protein, or both types of interactions. The time of addition experiments may suggest whether the compounds could affect early steps in infection (e.g. disassembly) or late steps (e. g. assembly) or at multiple steps. We hypothesize that compounds that led to higher fluorescence inhibit new core assembly and thus limit production of infectious virus. Compounds 1PA and 7AA were consistent with this idea. They were only an effective antiviral if added continuously or after virus absorption (Figure 5A, 5B), and much of the antiviral activity was lost if this compound was added only during virus absorption (Figure 5C). Compounds 4BA and 4CA were antivirals regardless of time of addition. Compounds that led to lower fluorescence were hypothesized to inhibit nucleocapsid core disassembly, an earlier part of the virus life cycle. Our results show 4BSA, NNU, and 2CA were effective antivirals even when added only during virus absorption (Figure 5C) consistent with 
these compounds acting during an early step of the viral life cycle. 5NBSA worked the best when added continuously, perhaps working post-disassembly.

Plaque assays reproducibly showed that eight of the compounds identified in our screen inhibited production of infectious virus (multiple independent virus preparations) (Figure 5). Many high throughput screens that identify new antiviral compounds use reporter-based assays to quickly look for a 50-75\% reduction in reporter activity (8-11). We initially sought to confirm the antiviral activity of all our compounds by using luciferase reporter viruses. We inserted luciferase into either a hypervariable loop of nsP3 (nsP3:luciferase) or after capsid protein (capsid:luciferase) $(61,62)$. CHIKV containing the luciferase reporter was added at an MOI $=0.01$ and rocked for 1 hour. Then the cells were washed and each of the eight compounds was added with fresh media. After 6 or 9 hours when using the nsP3:luciferase or capsid:luciferase virus (when maximum signal was observed), cells were lysed and luciferase activity determined. In our hands, most of the eight antiviral candidates failed to yield consistent luciferase activity results, thereby making it difficult to estimate the effect of the compounds (Supplemental Figure 2). Only 4BSA consistently and reproducibly inhibited the luciferase activity while the other antiviral compounds found in our screen had much wider variation. We found the reporter assay was biased towards identifying compounds that would inhibit entry and replication since time points were taken relatively early in the viral lifecycle. These data suggest that compounds that target the later stages of assembly such as core assembly, particle assembly, and have subsequent effects in particle spread, may be missed in this type of reporter screen.

\subsection{Efficacy of antiviral compounds in CHIKV infection}


We next tested the dose-dependence inhibition of our most inhibitory compounds (4BA, 1PA, 4BSA, and NUU) to estimate their $\mathrm{EC}_{50}$ or the half-maximal effective concentration. Following the addition scheme of Figure 5B, cells were treated with different concentrations of compound after virus adsorption for one hour. EC50 values for 4BA was $0.94 \mu \mathrm{M}$, 1PA was 1.19 $\mu \mathrm{M}$, 4BSA was $0.73 \mu \mathrm{M}$, and NUU was $1.23 \mu \mathrm{M}$ (Figure 6). When we compare these values to what was observed in our initial in vitro assays, we see that similar concentrations of compound are required to obtain inhibition of infectious particles in cell culture and CLP assembly in vitro. We see 0.94 vs $1.73 \mu \mathrm{M}$ for compound 4BA, 1.19 vs. $1.75 \mu \mathrm{M}$ for $1 \mathrm{PA}, 0.73$ vs. $2.44 \mu \mathrm{M}$ for 4BSA, and 1.23 vs $5.34 \mu \mathrm{M}$ for NNU when comparing the in vivo to the in vitro dose responses (Figure 6 and Supplementary Figure 1). The largest difference between in vivo and in vitro studies was an approximately 4-fold difference for NNU.

The $\mathrm{EC}_{50}$ observed by our study (Figure 6) indicate that four compounds are promising leads. Several groups have studied the antiviral properties of dioxane and its derivatives which bind in the hydrophobic pocket of capsid protein and subsequently interfere with the capsid-E2 interaction (17-19). Like Sharma et al. saw with CHIKV and picolic, we observed the best inhibition when 4BSA and virus were added simultaneously. However, they reported that $2 \mathrm{mM}$ of picolic acid was needed to inhibit infectious virus production by 50-60\% (19); in contrast, $<2 \mu \mathrm{M}$ of the four compounds identified by our study was needed to reduce infectious virus production by $50 \%$.

\subsection{Core assembly is targeted by compound $4 B S A$}

The four compounds that we focused on reduced the number of infectious particles released during a virus infection. Their effectiveness depends on the time of their addition, and their $\mathrm{EC}_{50}$ 
values range from 0.7-1.25 $\mu \mathrm{M}$. Our initial screen looked at modulators of core assembly. Our best inhibitor, based on dose response and inhibition of infectious virus, was 4BSA. To determine if 4BSA inhibited core assembly in CHIKV-infected cells, we examined lysate from infected cells with and without compound via centrifugation through a sucrose gradient (65). During a CHIKV infection, nucleocapsid cores form in the cytoplasm and are then enveloped by the viral glycoproteins and bud from the cell. Fractions from the gradient were analyzed by western blot probing for capsid proteins. Virus-infected cells show capsid protein at the top and midway through the sucrose gradient (Figure 7, left panel), consistent with free protein and assembled cytoplasmic cores (65). In contrast, cells treated with 4BSA did not form detectable amounts of cores (Figure 7, right panel). The low overall abundance of capsid protein in cells treated with virus and 4BSA could be the cumulative result of 4BSA activity interfering with the initial disassembly of the virus core, reducing viral replication and new virion propagation, and decreasing amounts of viral spread.

Viral genomes are present in both infectious and non-infectious particles. To determine if the total amount of particles released was altered in the presence of these compound, we determined the genome copies in released CHIKV. CHIKV was added to cells and after adsorption, compound was added, similar to Figure 5B. After 24 hours, media was collected and assayed by qRT-PCR (Figure 6). All four compounds affected the yield of total particles by less than one$\log$ though infectious particles decreased by more than 1-log. These results suggest that viral genome are packaged in the presence of compound but the genome is not able to infect new cells. 


\section{Conclusions}

In summary, we used a novel FRET-based assay to screen 10,000 compounds for their ability to inhibit or promote assembly of core-like particles. Of the initial 106 hits, eight compounds were further assessed due to their potent in vitro dose response and their lack of cellular toxicity. From this group, we identified four compounds that could reduce production of infectious virus by at least $1-\log$ and at least one of these compounds interferes with nucleocapsid core assembly in vivo. These results indicate that compounds with the ability to modulate core-like particle assembly also have potent antiviral activity. Our work adds to the growing body of evidence that suggest that targeting the capsid protein is an effective strategy to find new antivirals.

\section{Acknowledgments}

We thank members of the Mukhopadhyay and Zlotnick lab for scientific discussions. This work was supported by Assembly Biosciences (SM). AZ associated with biotechnology companies that focus on Hepatitis B virus. 
Figure Legends

Figure 1 - Schematic of the expected outcomes of the FRET-based assay for nucleic acid packaging in CLPs. (A) CLP assay using purified capsid protein and fluorescently labeled DNA oligos that provides the baseline fluorescence. (B-E) Expected outcomes of how fluorescence signal could increase representing less overall oligo packaged (B and C) or decrease representing more overall oligo packaged (D and $\mathrm{E}$ ) in the presence of added compound.

Figure 2 - Distribution of normalized fluorescence values from both screens. (A) Screen performed at low ionic strength and (B) at moderate strength. Increased fluorescence values $1 \sigma$, $2 \sigma$, and $3 \sigma$ from the average shown in shades of blue (lightest to darkest, respectively) and decreased fluorescence values with $1 \sigma, 2 \sigma$, and $3 \sigma$ from the average shown in shades of green (lightest to darkest, respectively). Actual number of hits and percentage of the total shown to the right of each histogram.

Figure 3 - Forty-five modulators of CLP assembly that were selected for further study. (A) 19 compounds identified in both the low and moderate ionic strength screen increased fluorescence during CLP assembly. Compounds $3 \sigma$ above the normalized fluorescence in the low ionic strength screen was compared to compound $2 \sigma$ above the normalize fluorescence in the moderate ionic strength. (B) 26 compounds that decreased fluorescence identified in both screens. Here, the cut-off of $3 \sigma$ was used in the moderate ionic strength and $2 \sigma$ from the low ionic strength screen.

Figure 4 - Toxicity assessment of compounds in cell culture. BHK cells were incubated with $10 \mu \mathrm{M}$ of compound only for 24 hours and then ATP levels were assessed using Cell Titer Glow. Compounds that increase fluorescence, possible assembly inhibitors, are shown with gray bars; compounds that decrease fluorescence, possible assembly enhancers, are shown with black bars. Cells incubated with virus and DMSO served as positive and negative controls, respectively. These data are the averages of 3 independent experiments performed in triplicate. Error bars indicate the standard deviation

Figure 5 - Antiviral activity of compounds as a function of their time-of-addition. BHK cells were infected with CHIKV and $10 \mu \mathrm{M}$ of compound was added (A) continuously, (B) after virus absorption, or $(\mathrm{C})$ during absorption of the virus. In left panel, compounds that increase fluorescence are shown with gray bars; compounds that decrease fluorescence are shown with black bars. In the experimental flowchart (right panels), the gray arrow indicates when compound was added. Supernatants were collected 24 hpi and plaque assays were used to determine the amounts of infectious virus. These data are averaged from three independent experiments. Error bars indicate the standard deviation.

Figure 6 - Four compounds have $\mathrm{EC}_{50}$ values in the $\mu \mathrm{M}$ range in vivo. $\mathrm{BHK}$ cells were infected with CHIKV and $10 \mu \mathrm{M}$ of compound (A) 4BA, (B) 1PA, (C) 4BSA, and (D) NNU. was added immediately after virus absorption. Supernatants were collected 24 hpi for plaque assays. $\mathrm{EC}_{50}$ values were $0.94 \mu \mathrm{M}$ for $4 \mathrm{BA}, 1.19 \mu \mathrm{M}$ for $1 \mathrm{PA}, 0.73 \mu \mathrm{M}$ for $4 \mathrm{BSA}$, and $1.23 \mu \mathrm{M}$ for NNU. These representative data are from one of three independent experiments. Why do 4BA and 1PA only go to about $20 \%$ ? 
Figure 7 - 4BSA inhibits nucleocapsid core assembly in CHIKV-infected cells. BHK cells were infected with CHIKV and either DMSO (left) or $10 \mu \mathrm{M}$ of 4BSA (right) was added immediately after virus absorption. Cells were lysed and nucleocapsid cores were isolated by density centrifugation. Fractions were collected and assessed for the presence of capsid protein by western blot. These representative data are from one of two independent experiments.

Figure 8 - Total number of virus particles released are slightly affected by the presence of compound. BHK cells were infected with CHIKV and $10 \mu \mathrm{M}$ of compound was added immediately after virus absorption (similar to Figure 5B). Compounds that increase fluorescence are shown with gray bars; compounds that decrease fluorescence are shown with black bars. Supernatants were collected 24 hpi for qPCR studies. These data are averaged from three independent experiments. Error bars indicate the standard deviation. 
References:

1. Ganesan VK, Duan B, Reid SP. 2017. Chikungunya Virus: Pathophysiology, Mechanism, and Modeling. Viruses 9.

2. Patterson J, Sammon M, Garg M. 2016. Dengue, Zika and Chikungunya: Emerging Arboviruses in the New World. West J Emerg Med 17:671-679.

3. Goupil BA, Mores CN. 2016. A Review of Chikungunya Virus-induced Arthralgia: Clinical Manifestations, Therapeutics, and Pathogenesis. Open Rheumatol J 10:129-140.

4. Powers AM. 2018. Vaccine and Therapeutic Options To Control Chikungunya Virus. Clin Microbiol Rev 31.

5. McCarthy MK, Davenport BJJ, Morrison TE. 2019. Chronic Chikungunya Virus Disease. Curr Top Microbiol Immunol doi:10.1007/82_2018_147.

6. Silva LA, Dermody TS. 2017. Chikungunya virus: epidemiology, replication, disease mechanisms, and prospective intervention strategies. J Clin Invest 127:737-749.

7. Tsetsarkin KA, Vanlandingham DL, McGee CE, Higgs S. 2007. A single mutation in chikungunya virus affects vector specificity and epidemic potential. PLoS Pathog 3:e201.

8. Feibelman KM, Fuller BP, Li L, LaBarbera DV, Geiss BJ. 2018. Identification of small molecule inhibitors of the Chikungunya virus nsP1 RNA capping enzyme. Antiviral Res 154:124-131.

9. Pohjala L, Utt A, Varjak M, Lulla A, Merits A, Ahola T, Tammela P. 2011. Inhibitors of alphavirus entry and replication identified with a stable Chikungunya replicon cell line and virusbased assays. PLoS One 6:e28923.

10. Ching KC, L FPN, Chai CLL. 2017. A compendium of small molecule direct-acting and hosttargeting inhibitors as therapies against alphaviruses. J Antimicrob Chemother 72:2973-2989.

11. Das PK, Puusepp L, Varghese FS, Utt A, Ahola T, Kananovich DG, Lopp M, Merits A, Karelson M. 2016. Design and Validation of Novel Chikungunya Virus Protease Inhibitors. Antimicrob Agents Chemother 60:7382-7395.

12. Abdelnabi R, Neyts J, Delang L. 2017. Chikungunya virus infections: time to act, time to treat. Curr Opin Virol 24:25-30.

13. Abdelnabi R, Neyts J, Delang L. 2016. Antiviral Strategies Against Chikungunya Virus. Methods Mol Biol 1426:243-253.

14. Ehteshami M, Tao S, Zandi K, Hsiao HM, Jiang Y, Hammond E, Amblard F, Russell OO, Merits A, Schinazi RF. 2017. Characterization of beta-d-N(4)-Hydroxycytidine as a Novel Inhibitor of Chikungunya Virus. Antimicrob Agents Chemother 61.

15. Kaur P, Thiruchelvan M, Lee RC, Chen H, Chen KC, Ng ML, Chu JJ. 2013. Inhibition of chikungunya virus replication by harringtonine, a novel antiviral that suppresses viral protein expression. Antimicrob Agents Chemother 57:155-167.

16. Varghese FS, Kaukinen P, Glasker S, Bespalov M, Hanski L, Wennerberg K, Kummerer BM, Ahola T. 2016. Discovery of berberine, abamectin and ivermectin as antivirals against chikungunya and other alphaviruses. Antiviral Res 126:117-124.

17. Sharma R, Kesari P, Kumar P, Tomar S. 2018. Structure-function insights into chikungunya virus capsid protein: Small molecules targeting capsid hydrophobic pocket. Virology 515:223234.

18. Aggarwal M, Tapas S, Preeti, Siwach A, Kumar P, Kuhn RJ, Tomar S. 2012. Crystal structure of aura virus capsid protease and its complex with dioxane: new insights into capsidglycoprotein molecular contacts. PLoS One 7:e51288. 
19. Sharma R, Fatma B, Saha A, Bajpai S, Sistla S, Dash PK, Parida M, Kumar P, Tomar S. 2016. Inhibition of chikungunya virus by picolinate that targets viral capsid protein. Virology 498:265-276.

20. Ashbrook AW, Lentscher AJ, Zamora PF, Silva LA, May NA, Bauer JA, Morrison TE, Dermody TS. 2016. Antagonism of the Sodium-Potassium ATPase Impairs Chikungunya Virus Infection. MBio 7.

21. Lundberg L, Pinkham C, de la Fuente C, Brahms A, Shafagati N, Wagstaff KM, Jans DA, Tamir S, Kehn-Hall K. 2016. Selective Inhibitor of Nuclear Export (SINE) Compounds Alter New World Alphavirus Capsid Localization and Reduce Viral Replication in Mammalian Cells. PLoS Neg1 Trop Dis 10:e0005122.

22. Lundberg L, Pinkham C, Baer A, Amaya M, Narayanan A, Wagstaff KM, Jans DA, KehnHall K. 2013. Nuclear import and export inhibitors alter capsid protein distribution in mammalian cells and reduce Venezuelan Equine Encephalitis Virus replication. Antiviral Res 100:662-672.

23. Mateo R, Nagamine CM, Kirkegaard K. 2015. Suppression of Drug Resistance in Dengue Virus. MBio 6:e01960-01915.

24. Tanner EJ, Liu HM, Oberste MS, Pallansch M, Collett MS, Kirkegaard K. 2014. Dominant drug targets suppress the emergence of antiviral resistance. Elife $\mathbf{3}$.

25. Byrd CM, Dai D, Grosenbach DW, Berhanu A, Jones KF, Cardwell KB, Schneider C, Wineinger KA, Page JM, Harver C, Stavale E, Tyavanagimatt S, Stone MA, Bartenschlager R, Scaturro P, Hruby DE, Jordan R. 2013. A novel inhibitor of dengue virus replication that targets the capsid protein. Antimicrob Agents Chemother 57:15-25.

26. Scaturro P, Trist IM, Paul D, Kumar A, Acosta EG, Byrd CM, Jordan R, Brancale A, Bartenschlager R. 2014. Characterization of the mode of action of a potent dengue virus capsid inhibitor. J Virol 88:11540-11555.

27. Deres K, Schroder CH, Paessens A, Goldmann S, Hacker HJ, Weber O, Kramer T, Niewohner U, Pleiss U, Stoltefuss J, Graef E, Koletzki D, Masantschek RN, Reimann A, Jaeger R, Gross R, Beckermann B, Schlemmer KH, Haebich D, Rubsamen-Waigmann H. 2003. Inhibition of hepatitis B virus replication by drug-induced depletion of nucleocapsids. Science 299:893-896.

28. Stray SJ, Zlotnick A. 2006. BAY 41-4109 has multiple effects on Hepatitis B virus capsid assembly. J Mol Recognit 19:542-548.

29. Stray SJ, Bourne CR, Punna S, Lewis WG, Finn MG, Zlotnick A. 2005. A heteroaryldihydropyrimidine activates and can misdirect hepatitis B virus capsid assembly. Proc Natl Acad Sci U S A 102:8138-8143.

30. Bourne CR, Finn MG, Zlotnick A. 2006. Global structural changes in hepatitis B virus capsids induced by the assembly effector HAP1. J Virol 80:11055-11061.

31. Katen SP, Chirapu SR, Finn MG, Zlotnick A. 2010. Trapping of hepatitis B virus capsid assembly intermediates by phenylpropenamide assembly accelerators. ACS Chem Biol 5:11251136.

32. Smith TJ, Kremer MJ, Luo M, Vriend G, Arnold E, Kamer G, Rossmann MG, McKinlay MA, Diana GD, Otto MJ. 1986. The site of attachment in human rhinovirus 14 for antiviral agents that inhibit uncoating. Science 233:1286-1293.

33. Li Y, Zhou Z, Post CB. 2005. Dissociation of an antiviral compound from the internal pocket of human rhinovirus 14 capsid. Proc Natl Acad Sci U S A 102:7529-7534.

34. Lewis JK, Bothner B, Smith TJ, Siuzdak G. 1998. Antiviral agent blocks breathing of the common cold virus. Proc Natl Acad Sci U S A 95:6774-6778.

35. Sticht J, Humbert M, Findlow S, Bodem J, Muller B, Dietrich U, Werner J, Krausslich HG. 2005. A peptide inhibitor of HIV-1 assembly in vitro. Nat Struct Mol Biol 12:671-677.

36. Adamson CS, Freed EO. 2010. Novel approaches to inhibiting HIV-1 replication. Antiviral Res 85:119-141. 
37. Timilsina U, Ghimire D, Timalsina B, Nitz TJ, Wild CT, Freed EO, Gaur R. 2016 . Identification of potent maturation inhibitors against HIV-1 clade C. Sci Rep 6:27403.

38. Waki K, Durell SR, Soheilian F, Nagashima K, Butler SL, Freed EO. 2012. Structural and functional insights into the HIV-1 maturation inhibitor binding pocket. PLoS Pathog 8:e1002997.

39. Li F, Goila-Gaur R, Salzwedel K, Kilgore NR, Reddick M, Matallana C, Castillo A, Zoumplis D, Martin DE, Orenstein JM, Allaway GP, Freed EO, Wild CT. 2003. PA-457: a potent HIV inhibitor that disrupts core condensation by targeting a late step in Gag processing. Proc Natl Acad Sci U S A 100:13555-13560.

40. Lemke CT, Titolo S, von Schwedler U, Goudreau N, Mercier JF, Wardrop E, Faucher AM, Coulombe R, Banik SS, Fader L, Gagnon A, Kawai SH, Rancourt J, Tremblay M, Yoakim C, Simoneau B, Archambault J, Sundquist WI, Mason SW. 2012. Distinct effects of two HIV-1 capsid assembly inhibitor families that bind the same site within the N-terminal domain of the viral CA protein. J Virol 86:6643-6655.

41. Wang W, Zhou J, Halambage UD, Jurado KA, Jamin AV, Wang Y, Engelman AN, Aiken C. 2017. Inhibition of HIV-1 Maturation via Small-Molecule Targeting of the Amino-Terminal Domain in the Viral Capsid Protein. J Virol 91.

42. Xu JP, Francis AC, Meuser ME, Mankowski M, Ptak RG, Rashad AA, Melikyan GB, Cocklin S. 2018. Exploring Modifications of an HIV-1 Capsid Inhibitor: Design, Synthesis, and Mechanism of Action. J Drug Des Res 5.

43. Yant SR, Mulato A, Stepan G, Villasenor AG, Jin D, Margot NA, Ahmadyar S, Ram RR, Somoza JR, Singer E, Wong M, Xu Y, Link JO, Cihlar T, Tse WC. 2019. GS-6207, A POTENT AND SELECTIVE FIRST-IN-CLASS LONG-ACTING HIV-1 CAPSID INHIBITOR, abstr CROI Conference on Retroviruses and Opportunistic Infections, Seattle, Washington,

44. Bhattacharya A, Alam SL, Fricke T, Zadrozny K, Sedzicki J, Taylor AB, Demeler B, Pornillos O, Ganser-Pornillos BK, Diaz-Griffero F, Ivanov DN, Yeager M. 2014. Structural basis of HIV-1 capsid recognition by PF74 and CPSF6. Proc Natl Acad Sci U S A 111:1862518630.

45. Kuhn RJ. 2013. Chapter 22: Togaviradae, p 629-650. In Knipe DM, Howley PM (ed), Fields' Virology. Lippincott Williams \& Wilkins, Philadelphia.

46. Jose J, Snyder JE, Kuhn RJ. 2009. A structural and functional perspective of alphavirus replication and assembly. Future Microbiol 4:837-856.

47. Zhang W, Mukhopadhyay S, Pletnev SV, Baker TS, Kuhn RJ, Rossmann MG. 2002. Placement of the structural proteins in Sindbis virus. J Virol 76:11645-11658.

48. Tellinghuisen TL, Hamburger AE, Fisher BR, Ostendorp R, Kuhn RJ. 1999. In vitro assembly of alphavirus cores by using nucleocapsid protein expressed in Escherichia coli. J Virol 73:5309-5319.

49. Cheng F, Tsvetkova IB, Khuong YL, Moore AW, Arnold RJ, Goicochea NL, Dragnea B, Mukhopadhyay S. 2013. The packaging of different cargo into enveloped viral nanoparticles. Mol Pharm 10:51-58.

50. Cheng F, Mukhopadhyay S. 2011. Generating enveloped virus-like particles with in vitro assembled cores. Virology 413:153-160.

51. Snyder JE, Azizgolshani O, Wu B, He Y, Lee AC, Jose J, Suter DM, Knobler CM, Gelbart WM, Kuhn RJ. 2011. Rescue of infectious particles from preassembled alphavirus nucleocapsid cores. J Virol 85:5773-5781.

52. Wang JC, Chen C, Rayaprolu V, Mukhopadhyay S, Zlotnick A. 2015. Self-Assembly of an Alphavirus Core-like Particle Is Distinguished by Strong Intersubunit Association Energy and Structural Defects. ACS Nano 9:8898-8906.

53. Rayaprolu V, Moore A, Wang JC, Goh BC, Perilla JR, Zlotnick A, Mukhopadhyay S. 2017. Length of encapsidated cargo impacts stability and structure of in vitro assembled alphavirus core-like particles. J Phys Condens Matter 29:484003. 
54. Mukhopadhyay S, Chipman PR, Hong EM, Kuhn RJ, Rossmann MG. 2002. In vitroassembled alphavirus core-like particles maintain a structure similar to that of nucleocapsid cores in mature virus. J Virol 76:11128-11132.

55. Wang JC, Mukhopadhyay S, Zlotnick A. 2018. Geometric Defects and Icosahedral Viruses. Viruses 10.

56. Goicochea NL, De M, Rotello VM, Mukhopadhyay S, Dragnea B. 2007. Core-like particles of an enveloped animal virus can self-assemble efficiently on artificial templates. Nano Lett 7:22812290

57. Zlotnick A, Vieweger S. 2019. Generalizable Assay For Virus Capsid Assembly. USA patent $10,208,358$.

58. Ashbrook AW, Burrack KS, Silva LA, Montgomery SA, Heise MT, Morrison TE, Dermody TS. 2014. Residue 82 of the Chikungunya virus E2 attachment protein modulates viral dissemination and arthritis in mice. J Virol 88:12180-12192.

59. Hong EM, Perera R, Kuhn RJ. 2006. Alphavirus capsid protein helix I controls a checkpoint in nucleocapsid core assembly. J Virol 80:8848-8855.

60. Team RC. 2013. R: A language and environment for statistical computing. http://www.Rproject.org/. Accessed

61. Kummerer BM, Grywna K, Glasker S, Wieseler J, Drosten C. 2012. Construction of an infectious Chikungunya virus cDNA clone and stable insertion of mCherry reporter genes at two different sites. J Gen Virol 93:1991-1995.

62. Sun C, Gardner CL, Watson AM, Ryman KD, Klimstra WB. 2014. Stable, high-level expression of reporter proteins from improved alphavirus expression vectors to track replication and dissemination during encephalitic and arthritogenic disease. J Virol 88:2035-2046.

63. Ramsey J, Renzi EC, Arnold RJ, Trinidad JC, Mukhopadhyay S. 2017. Palmitoylation of Sindbis Virus TF Protein Regulates Its Plasma Membrane Localization and Subsequent Incorporation into Virions. J Virol 91.

64. Sokoloski KJ, Hayes CA, Dunn MP, Balke JL, Hardy RW, Mukhopadhyay S. 2012. Sindbis virus infectivity improves during the course of infection in both mammalian and mosquito cells. Virus Res 167:26-33.

65. Lopez S, Yao JS, Kuhn RJ, Strauss EG, Strauss JH. 1994. Nucleocapsid-glycoprotein interactions required for assembly of alphaviruses. J Virol 68:1316-1323.

66. Brown RS, Wan JJ, Kielian M. 2018. The Alphavirus Exit Pathway: What We Know and What We Wish We Knew. Viruses 10.

67. Tellinghuisen TL, Perera R, Kuhn RJ. 2001. In vitro assembly of Sindbis virus core-like particles from cross-linked dimers of truncated and mutant capsid proteins. J Virol 75:2810-2817.

68. Warrier R, Linger BR, Golden BL, Kuhn RJ. 2008. Role of sindbis virus capsid protein region II in nucleocapsid core assembly and encapsidation of genomic RNA. J Virol 82:4461-4470.

69. Perera R, Owen KE, Tellinghuisen TL, Gorbalenya AE, Kuhn RJ. 2001. Alphavirus nucleocapsid protein contains a putative coiled coil alpha-helix important for core assembly. $\mathrm{J}$ Virol 75:1-10. 


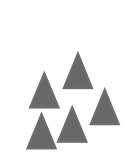

Purified capsid protein

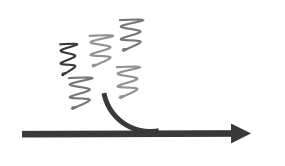

Oligo mix

Clix

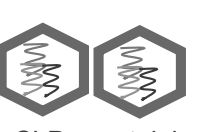
oligos
$+\xi_{\xi}^{\xi}+\Delta$

Little unpackaged oligo and capsid protein
CLPs containing

Control fluorescence
Fewer CLPs More unpackaged oligo, assembled More free capsid protein

Higher fluorescence

COMPOUND+

Purified capsid protein

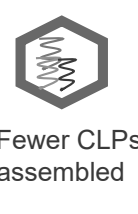

More unpackaged oligo,
More free capsid protein

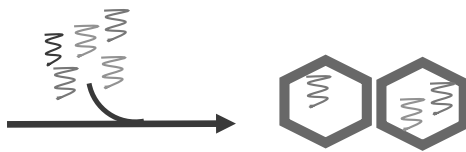

$+\sum^{\sum} \sum_{j}^{3}+4$

Higher fluorescence

CLPs containing More unpackaged oligo
fewer oligos

Purified capsid

Oligo mix

fewer oligos

4

$\infty$

은

$\frac{\pi}{\frac{7}{0}}$

$\stackrel{0}{\Sigma}$

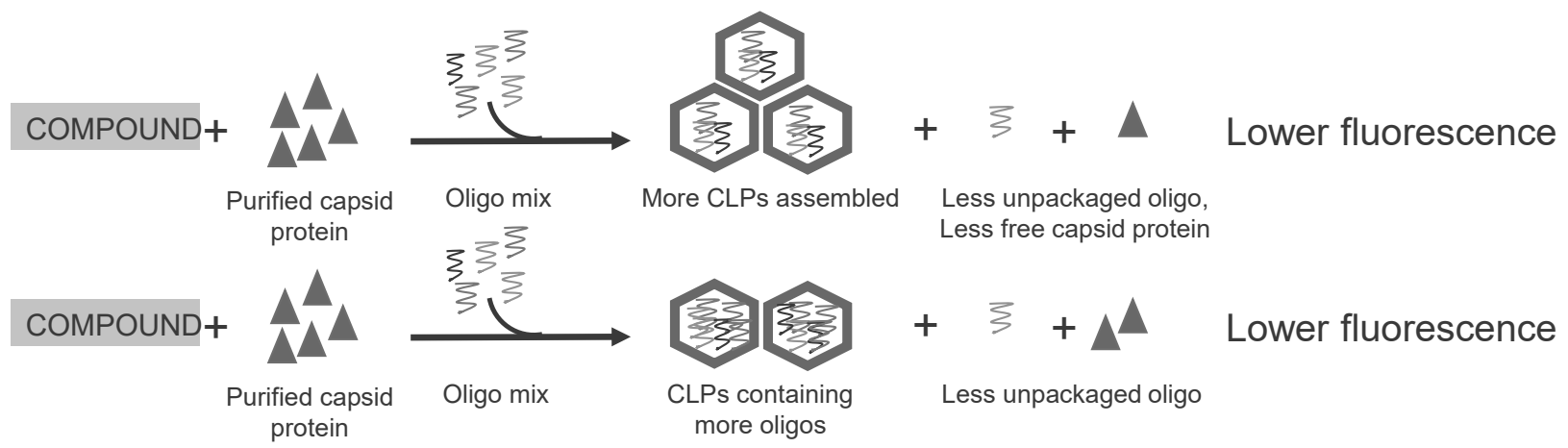


bioRxiv preprint doi: https://doi.org/10.1101/774943; this version posted September 19, 2019. The copyright holder for this preprint (which was not certified by peer review) is the author/funder. All rights reserved. No reuse allowed without permission.

2A Hits from low ionic strength screen

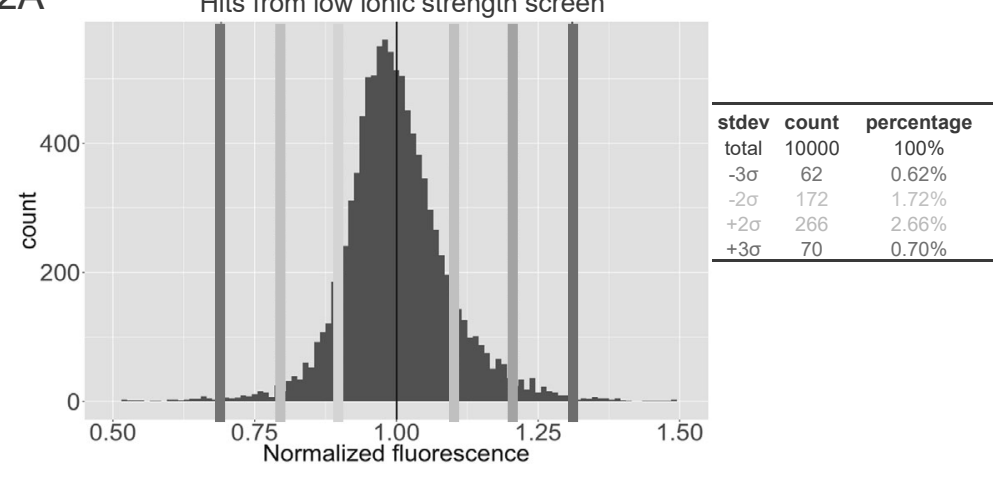

2B

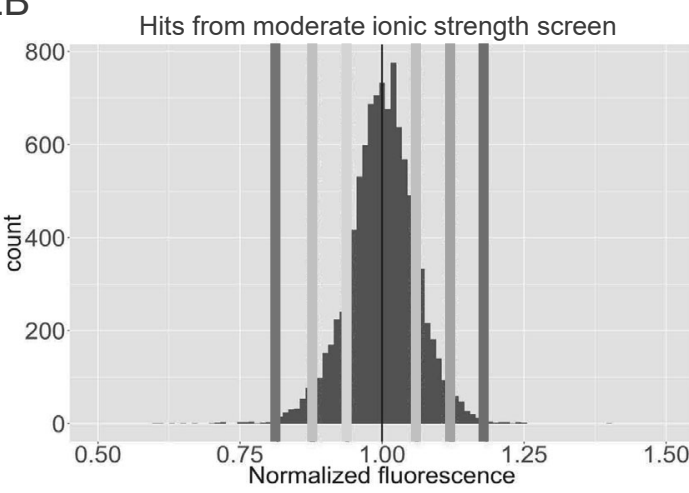

19 hits common in both 3A screens that increased fluorescence

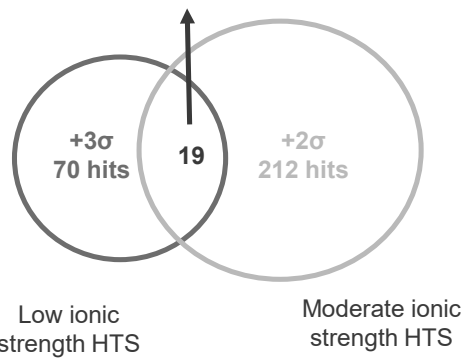

26 hits common in both screens that decreased

3B fluorescence

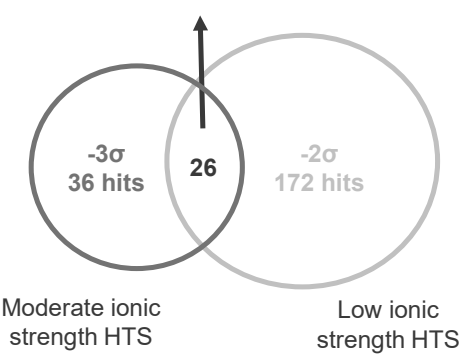


4

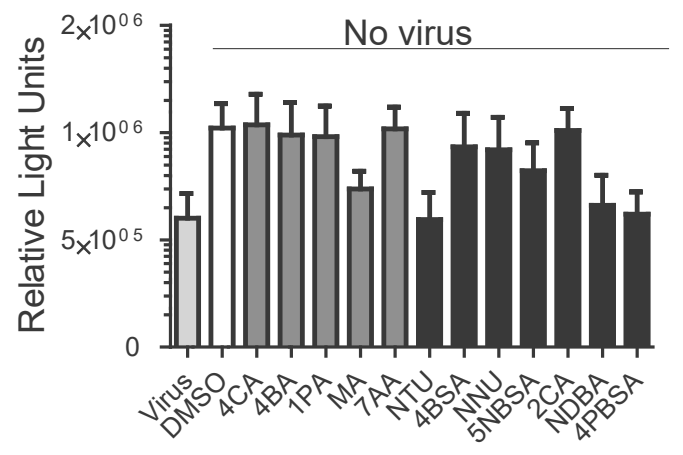

$5 \mathrm{~A}$
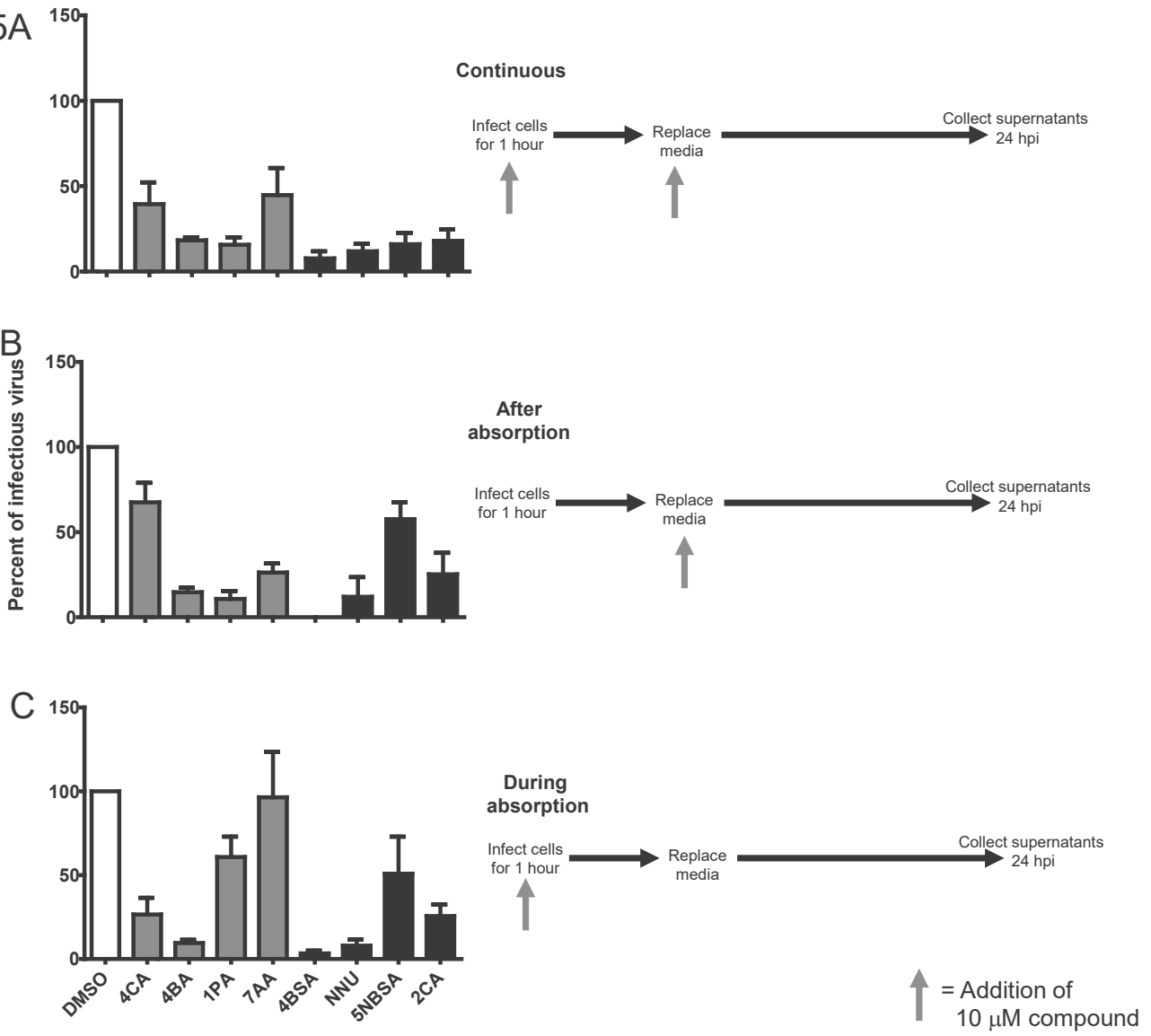

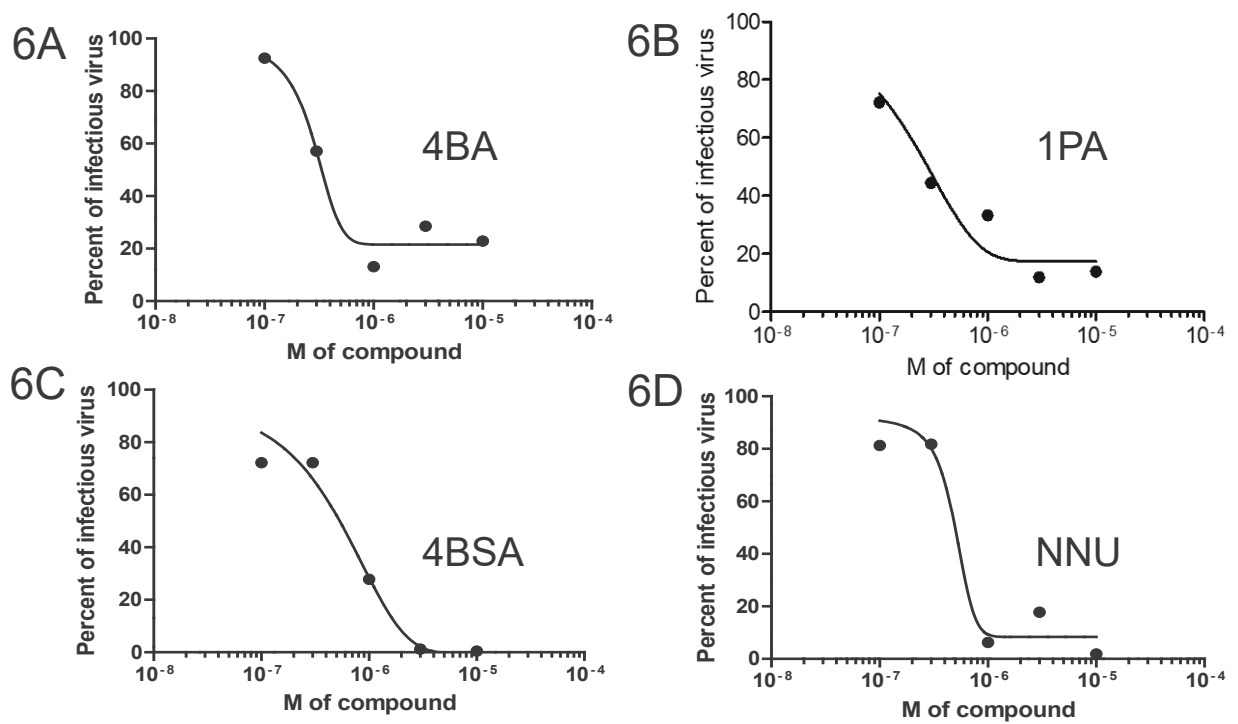

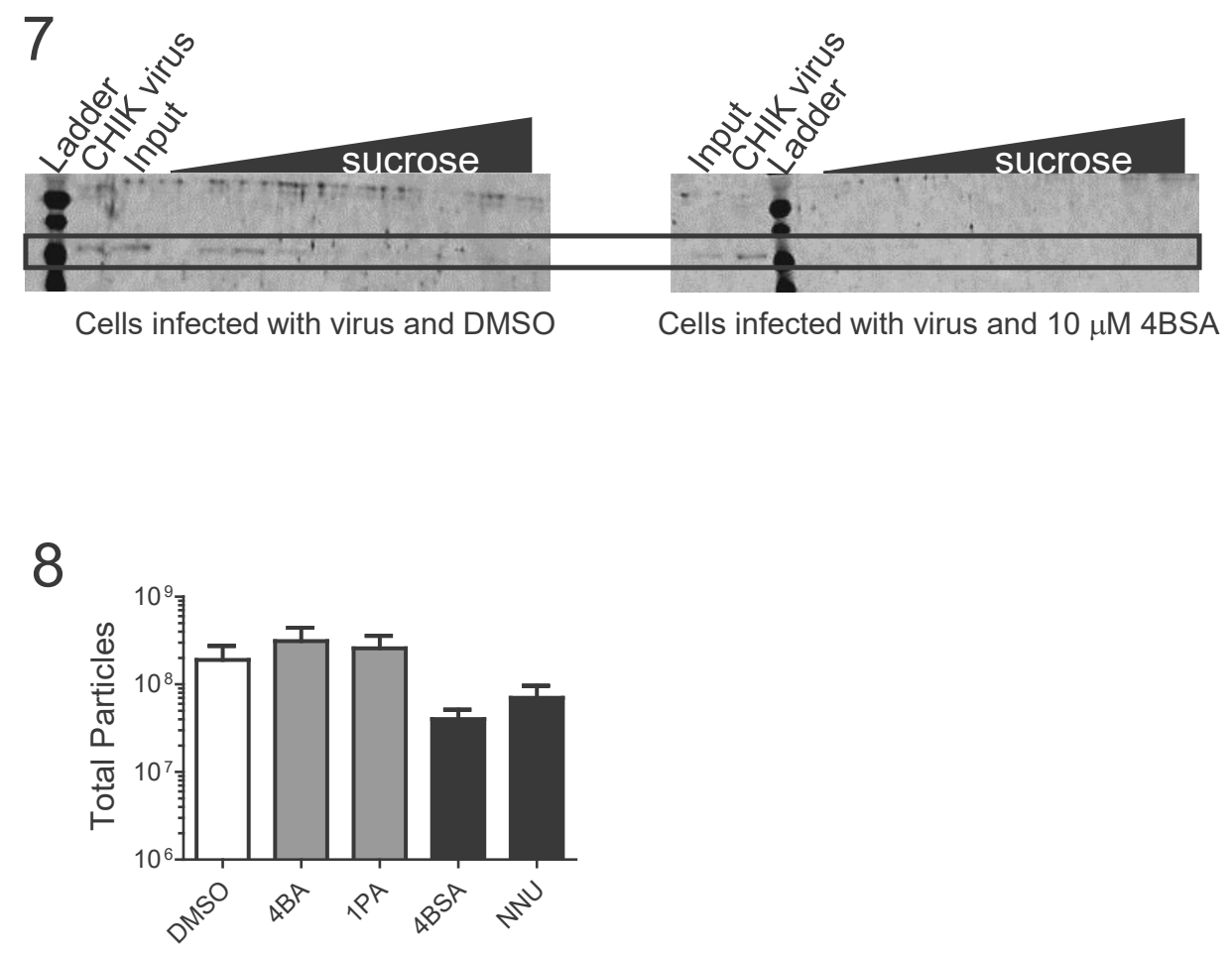
bioRxiv preprint doi: https://doi.org/10.1101/774943; this version posted September 19, 2019. The copyright holder for this preprint (which was not certified by peer review) is the author/funder. All rights reserved. No reuse allowed without permission.

Supplemental figures 

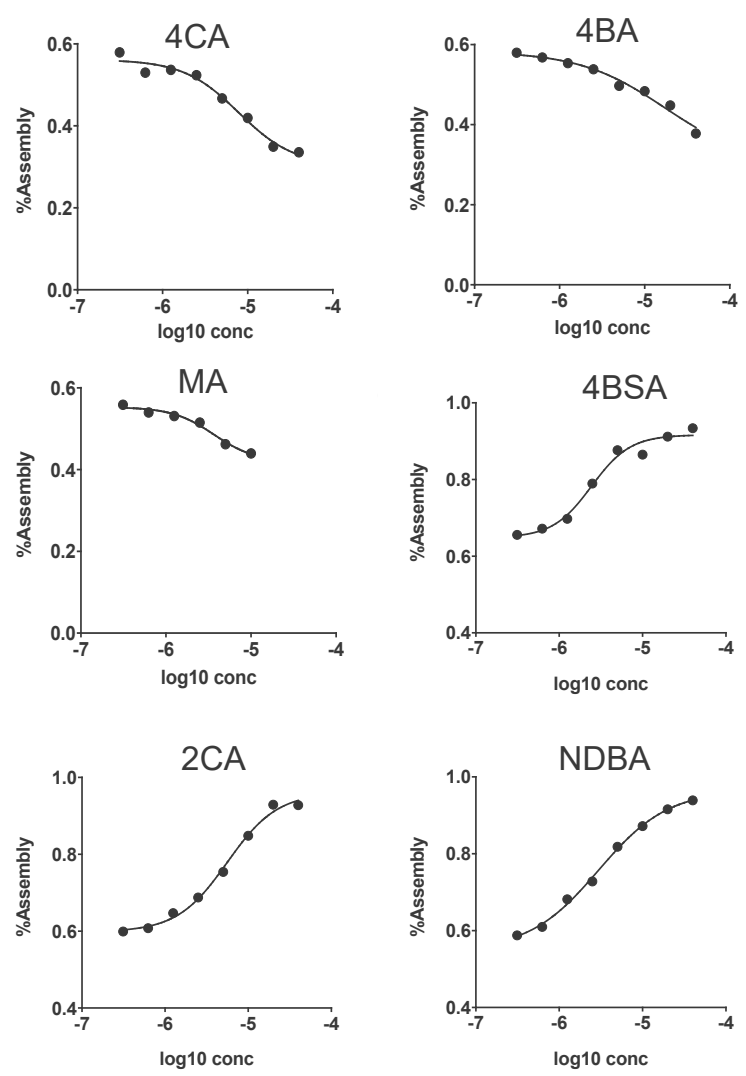
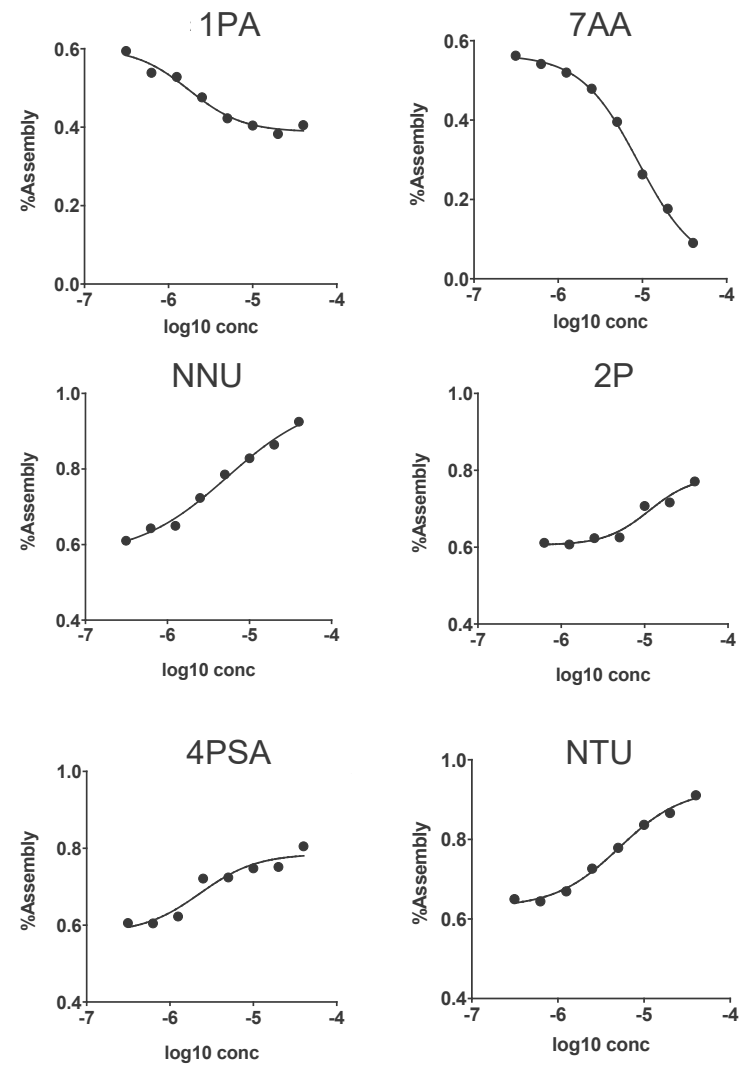

Supplemental Figure 1. Forty-five of the CLP modulators identified in the HTS were validated by determining CLP assembly in vitro as a function of compound concentration. An increase in fluorescence signal correlated to low assembly and a decrease in fluorescence signal correlates to high assembly. Dose response of compounds that increase fluorescence were tested at $320 \mathrm{mM} \mathrm{NaCl}$ and dose response of compounds that decrease were tested at 570 $\mathrm{mM}$. The twelve compounds shown here were selected to be further tested in tissue culture assays using intact CHIK virus. 
A

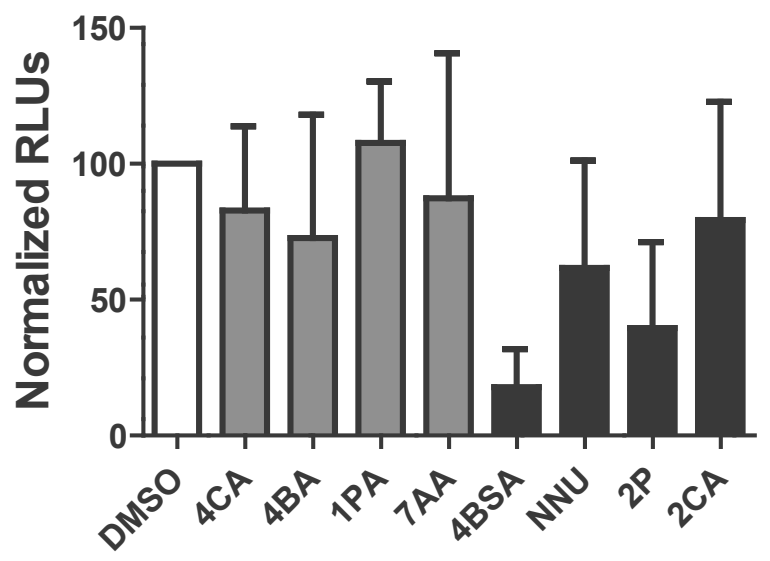

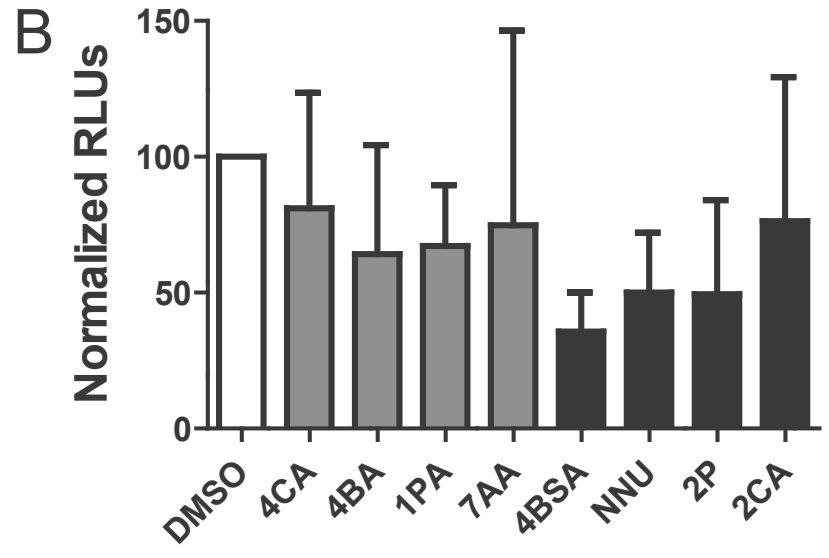

Supplemental Figure 2. Sensitivity of reporter gene assays to compounds identified by the assembly assay. BHK cells were infected with CHIKV nsP3:Iuciferase (A) or capsid:Iuciferase (B) and $10 \mu \mathrm{M}$ of compound was added immediately after virus absorption. Cells lysates were assessed for luciferase either 6 hpi (A) or 9 hpi (B). These data are averaged from 3 independent experiments; each performed in triplicate. Medium gray and black bars represent compounds identified in the inhibitor or promoter screen, respectively. 